\title{
Trace Elements in the Beach and Near Shore Sediments of the Mediterranean Coast of the Eastern Part of Nile Delta
}

\author{
M.M. El Banna ${ }^{\text {a }}$, O. El Halabe ${ }^{\text {b }}$ M.M. Khalil ${ }^{\text {b* }}$ \\ ${ }^{a}$ National Water Research Center, Coastal Research Institute, 15 El Pharaana Street, 21514, Alexandria, Egypt \\ ${ }^{\mathrm{b}}$ Geology Department, Faculty of Science, Damietta University, Egypt
}

\begin{abstract}
Heavy metals in the beach and near shore seafloor sediments along the Mediterranean coast of the eastern part of Nile Delta were extracted from sediments using the EPA (Environmental protection Agency) Test Method 1311-TCLP, (Toxicity Characteristic Leaching Procedure) in order to identify their distribution, characterize the Quality of the coastal sediments and predicted the potential point sources of sediments pollution in the area.

It has been found that Aluminum, Barium, Manganese, Lead, Cobalt, Chromium, Cupper, Iron, and Zinc are present within the permissible level of USA sediment quality Guidelines (New York State Department of Environmental Conservation). The content levels of Mercury (0.379 - 2.96) and Cadmium (0.002 - 6.7) exceed the risk levels for metals contamination in sediments.

The peak of cadmium content $(6.7 \mathrm{ppm})$ in the sediment samples near the dumping location of Gamasa drain identified the drain as a point source for cadmium contamination.
\end{abstract}

Keywords: Heavy metals, pollution, shore line, trace elements

\section{Introduction}

The Mediterranean shore of the Nile Delta, consists of sandy beaches, these beaches are backed by coastal flats followed by coastal lagoons (from east to west, El Manzala, Burullus, Mariut and Idku). The coastal plain is characterized by a high rate of population growth, land use interference, ecosystem pollution and degradation, lack of appropriate institutional management system. Pollution becomes a serious problem affecting the coastal areas of the Nile Delta as a result of increasing population and human activities. The main sources of pollution are domestic sewage, hazardous industrial waste, fertilizers and pesticides from agricultural waste. These are discharging from drains, lagoons and Nile branches outlets, in addition to oil pollution from ships and oil terminals.

The study of marine sediments is an important tool for determining the actual condition of environmental pollution. Sediments are major repository of trace metals in the coastal marine environment [1] and reflect the changes occurring in the overlying water system; consequently analysis of trace metals is an important part of environmental pollution studies [2]. Several studies investigated the occurrence of trace metals in marine sediments of the Egyptian coast; El-Sayed [3] dealt with anthropogenic material in sediments from the Eastern harbor of Alexandria, El-Nady [4] studied heavy metals in Alexandria coast and its effect on marine 
animals.

Aboul Dahab and Halim [5] investigated spatial distribution of tin compounds in sediments of Alexandria coast, Nasr et al [6] studied pollution effects on the coastal sediments of Alexandria. Saad and Badr [7] dealt with copper speciation in sediments of the eastern harbor of Alexandria. Elewa [8] studied Heavy metals in Nile and drains waters and bottom sediments. The eastern part of the Nile Delta coast is inadequately studied in terms of sediment quality. The present study aims to explore the occurrence of the trace heavy metals in the beach and nearshore sediments in Mediterranean coast of the eastern part of Nile Delta to determine the actual condition of the environmental pollution in this part of the Nile Delta.

\section{Materials and methods}

\section{The study area}

The study area extends from the outlet of Damietta Nile branch to the East of Balteem resort in the West (about $80 \mathrm{~km}$ ). It includes the coast of Ras El Bar resort, Damietta harbour, and Gamasa resort, in addition to the eastern part of Balteem resort (Fig. 1a\&1b).

The coast in general is composed of medium, fine and very fine sands with shell fragments and appreciable amount of heavy minerals. Sand grains gradually decrease in size seawards with increasing the water depth. These sediments have been affected by the predominant eastward littoral current $[9,10]$. Inman and Zenkins [11] mentioned that the River Nile was the transporting agent of the sediments rich in heavy minerals for the Nile delta as well as for the entire Nile littoral cell that extends $500 \mathrm{~km}$ eastward to Akko, Israel.

\section{Sampling and Methodology}

More than sixty samples were collected during the beach profiles survey carried out by the Coastal Research Institute (CoRI) biannually through an intensive program of monitoring the changes in the Nile delta coast. Herein, samples of the annual profiles made in the 2010 were analyzed. Beach and seafloor samples of twenty one beach profiles covering the study area were analyzed. The profile lines are perpendicular to the coastline and extend seaward to about $6 \mathrm{~m}$ water depth or to 1200 meters maximum distance seaward.

Bottom Samples were collected at every 100 $\mathrm{m}$ along each profile using a grab sampler. Samples taken from zero, 100, and $300 \mathrm{~m}$ seaward distance from the baseline (fixed line on the beach) were chosen for the analysis in the present study except the first and second profiles in Ras El Bar sector, where there is no beach, samples taken from 100, 200 and 300 seaward distance from the baseline on the coast were analyzed.

The analyses were carried out in the laboratories of Musa Group, Jeddah, Saudi Arabia, using the most advanced methods of analysis; the ICP-OES (Thermo) model 2010. The study samples containing different percentages of the common silicate minerals and some carbonated and heavy minerals which are normally present in the sediments of the study area with the potential pollutants. The method of analysis was selected to extract pollutants only from sediment without the dissolution of the other common minerals.

Based in the geographical setting of the study area, it has been divided to the following four sectors; these sectors from east to west are: 1Ras El Bar, 2-Damietta port, 3- New DamiettaGamasa and 4- Balteem. Some beach profiles like No. 10 and 12 were used as a common profile in two adjacent zones (Table 1).

The first is Ras El Bar sector; it extends about $8 \mathrm{~km}$ westward starting from the mouth of Damietta Nile branch. In this area there are 7 surveyed beach profiles 1- 7 (Fig. 2). The second sector located east and west of Damietta port and has a length of about $4 \mathrm{~km}$. In this area there are 4 surveyed beach profiles 7- 10 (Fig. 2). The third sector (New Damietta city-Gamasa), it has a length of about $30 \mathrm{~km}$ and is covered by 10 beach profiles 10- 19. The forth zone (Balteem zone) is covered by 2 beach profiles $20-21$ and extends to about $5 \mathrm{~km}$.

\section{Extraction of the heavy trace metals}

Heavy metals were extracted from sediments using the EPA Test Method 1311 - TCLP, (Toxicity Characteristic Leaching Procedure). TCLP USEPA method of extraction is designed to determine the mobility of both organic and inorganic analysts present in liquid, solid, and multiphase wastes.

The TCLP analysis determines which of the contaminants identified by the United States Environmental Protection Agency (EPA) are 
present in the leach and their concentrations. Extraction also was carried out using DTPA (diethylenetriaminepentaacetic acid). This method is suitable for environmental applications. In this method we use a DTPA solution which containing calcium chloride $\left(\mathrm{CaCl}_{2}\right)$ and $\mathrm{HCL} 1: 1$ to adjust $\mathrm{pH}$ to $7.3 \pm 0.05$. This method is suitable for $\mathrm{Cd}, \mathrm{Cr}, \mathrm{Ni}, \mathrm{Pb}$ and $\mathrm{Zn}$ (modified from Lindsay and Norvell [12]).

\section{Analysis of heavy trace metals}

Samples were analyzed using Method WL272 (USEPA 2007) for total metals (except mercury). Samples were analyzed using ICP-AES instrument. Mercury method is WL41 (modified USEPA 245.1.) using the Cold Vapour Atomic Absorption Spectrometric method.

(a)

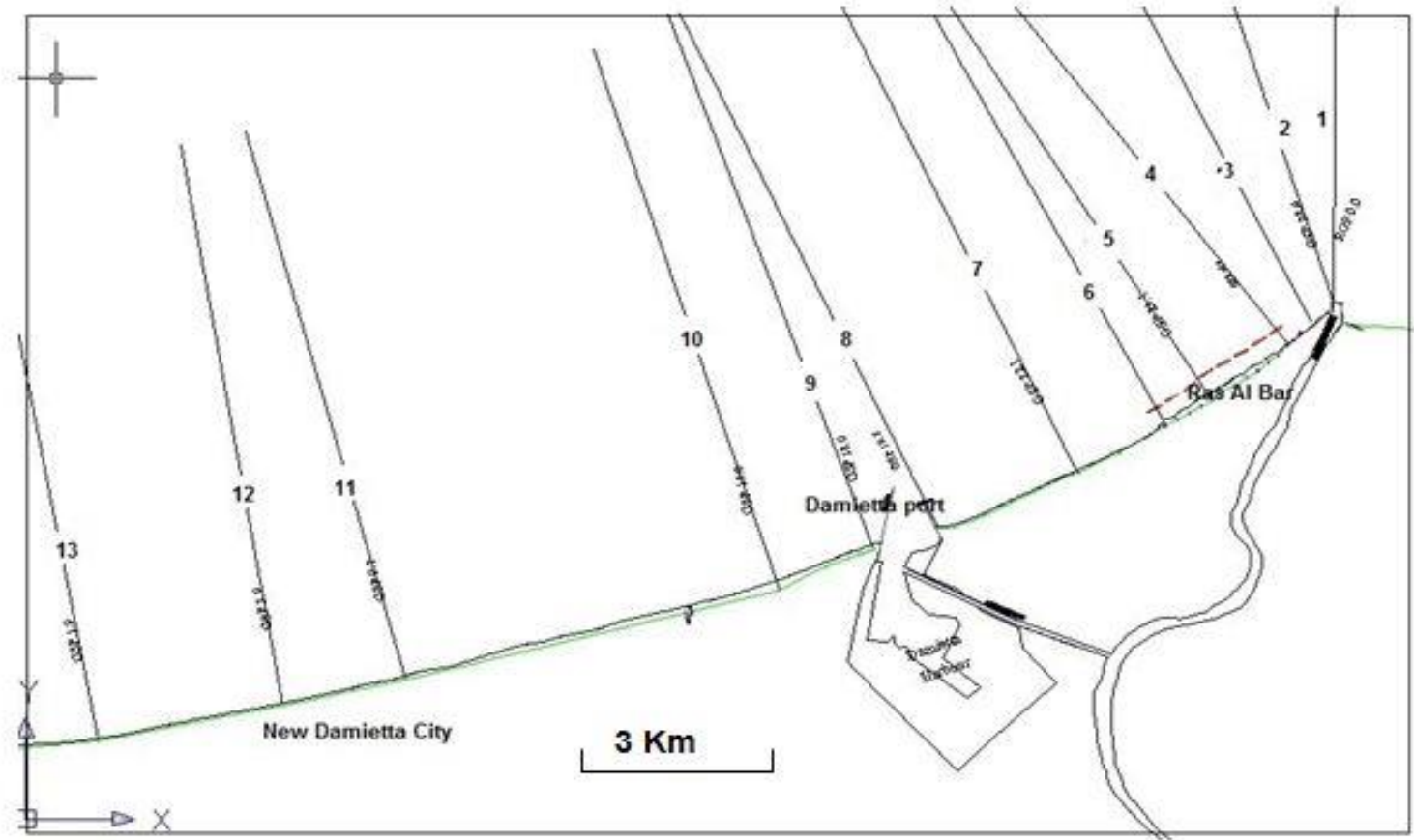

(b)

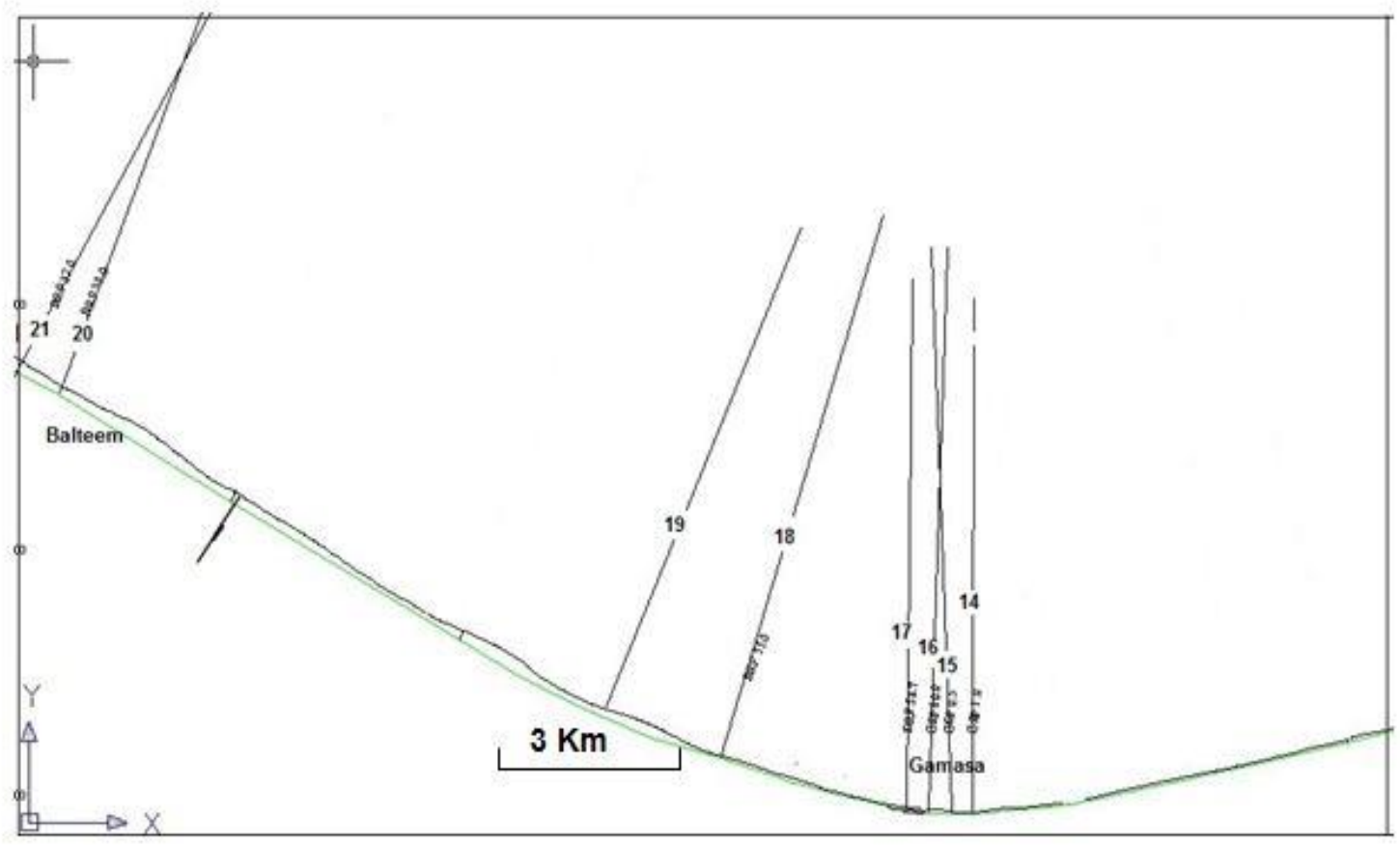

Fig. a Location map for the Eastern sector (a) and the Western sector (b) of the study area showing the location of beach profiles 
Table 1 Location of the Beach points of the studied Profiles

\begin{tabular}{|c|c|c|c|}
\hline Profile No & Sample No. & Latitude & Longitude \\
\hline 1 & $1-100$ & $31^{\circ} 31^{\prime} 47.36 " \mathrm{~N}$ & $31^{\circ} 50^{\prime} 38.54^{\prime \prime} \mathrm{E}$ \\
\hline 2 & $2-100$ & $31^{\circ} 31^{\prime} 47.19^{\prime \prime} \mathrm{N}$ & $31^{\circ} 50^{\prime} 37.36^{\prime \prime} \mathrm{E}$ \\
\hline 3 & $3-000$ & $31^{\circ} 31^{\prime} 34.15^{\prime \prime} \mathrm{N}$ & $31^{\circ} 50^{\prime} 25.61^{\prime \prime} \mathrm{E}$ \\
\hline 4 & $4-000$ & $31^{\circ} 31^{\prime} 17.93 " \mathrm{~N}$ & $31^{\circ} 50^{\prime} 02.53^{\prime \prime} \mathrm{E}$ \\
\hline 5 & $5-000$ & $31^{\circ} 30^{\prime} 49.31^{\prime \prime N}$ & $31^{\circ} 49^{\prime} 14.84^{\prime \prime E}$ \\
\hline 6 & $6-000$ & $31^{\circ} 30^{\prime} 26.60^{\prime \prime} \mathrm{N}$ & $31^{\circ} 48^{\prime} 31.95^{\prime \prime} \mathrm{E}$ \\
\hline 7 & $7 '-000$ & $31^{\circ} 29^{\prime} 56.35^{\prime \prime} \mathrm{N}$ & $31^{\circ} 47^{\prime} 32.46^{\prime \prime} \mathrm{E}$ \\
\hline 8 & $8-000$ & $31^{\circ} 29^{\prime} 08.87^{\prime \prime} \mathrm{N}$ & $31^{\circ} 45^{\prime} 52.09^{\prime \prime} \mathrm{E}$ \\
\hline 9 & $9-000$ & $31^{\circ} 29^{\prime} 03.38^{\prime \prime} \mathrm{N}$ & $31^{\circ} 45^{\prime} 06.03^{\prime \prime} \mathrm{E}$ \\
\hline 10 & $10-000$ & $31^{\circ} 28^{\prime} 38.79^{\prime \prime} \mathrm{N}$ & $31^{\circ} 43^{\prime} 56.53^{\prime \prime} \mathrm{E}$ \\
\hline 11 & $11-000$ & $31^{\circ} 27^{\prime} 33.23 " \mathrm{~N}$ & $31^{\circ} 39^{\prime} 29.82^{\prime \prime} \mathrm{E}$ \\
\hline 12 & $12-000$ & $31^{\circ} 27^{\prime} 14.27^{\prime \prime} \mathrm{N}$ & $31^{\circ} 38^{\prime} 01.44^{\prime \prime} \mathrm{E}$ \\
\hline 13 & $13-000$ & $31^{\circ} 26^{\prime} 49.61^{\prime \prime N}$ & $31^{\circ} 35^{\prime} 48.31^{\prime \prime} \mathrm{E}$ \\
\hline 14 & $14-000$ & $31^{\circ} 26^{\prime} 41.86^{\prime \prime} \mathrm{N}$ & $31^{\circ} 34^{\prime} 32.89^{\prime \prime} \mathrm{E}$ \\
\hline 15 & $15-000$ & $31^{\circ} 26^{\prime} 42.06^{\prime \prime} \mathrm{N}$ & $31^{\circ} 34^{\prime} 15.82^{\prime \prime} \mathrm{E}$ \\
\hline 16 & $16-000$ & $31^{\circ} 26^{\prime} 43.52^{\prime \prime} \mathrm{N}$ & $31^{\circ} 33^{\prime} 58.13^{\prime \prime} \mathrm{E}$ \\
\hline 17 & $17-000$ & $31^{\circ} 26^{\prime} 44.68 " \mathrm{~N}$ & $31^{\circ} 33^{\prime} 40.48^{\prime \prime} \mathrm{E}$ \\
\hline 18 & $18-000$ & $31^{\circ} 27^{\prime} 16.19^{\prime \prime} \mathrm{N}$ & $31^{\circ} 31^{\prime} 12.95^{\prime \prime} \mathrm{E}$ \\
\hline 19 & $19-000$ & $31^{\circ} 28^{\prime} 37.12^{\prime \prime} \mathrm{N}$ & $31^{\circ} 27^{\prime} 45.84^{\prime \prime} \mathrm{E}$ \\
\hline 20 & $20-000$ & $31^{\circ} 35^{\prime} 29.71 " \mathrm{~N}$ & $31^{\circ} 9^{\prime} 11.52^{\prime \prime} \mathrm{E}$ \\
\hline 21 & $21-000$ & $31^{\circ} 36^{\prime} 09.26^{\prime \prime} \mathrm{N}$ & $31^{\circ} 6^{\prime} 25.54 " \mathrm{E}$ \\
\hline
\end{tabular}

\section{Results and Discussion}

The analysis of heavy metals values were plotted and contoured on base maps of the study area using surfer software version. The detected heavy trace metals in the beach and near shore seafloor sediments of the study area are: Aluminum, Barium, Manganese, Lead, Phosphorus, sulfur, Mercury, Cadmium, Cobalt, Chromium, Cupper, Iron, and Zinc. Metal concentrations in the sediment (dry weight) ranged between 0.07$50.47 \mathrm{ppm}$ for Aluminum (Al), 0.036-61.7 ppm for Barium $(\mathrm{Ba}), \quad 8.868-348.8 \mathrm{ppm}$ for Manganese (Mn), 0.161-15.56 ppm for Lead $(\mathrm{Pb}), 0.379-2.69 \mathrm{ppm}$ for Mercury $(\mathrm{Hg}), 0.002$ $6.7 \mathrm{ppm}$ for Cadmium (Cd), 0.066-2.44 for Cobalt (Co), 0.108-0.412 ppm for Chromium $(\mathrm{Cr}), 0.016-10.37 \mathrm{ppm}$ for Cupper $(\mathrm{Cu}), 5.628$ $657.8 \mathrm{ppm}$ for Iron $(\mathrm{Fe})$, and $0.134-32.72 \mathrm{ppm}$ for Zinc (Zn).

According to Long and Morgan [13], Persaud et al. [14] sediments are considered contaminated with heavy metals if either condition shown in (Table 2) is exceeded. If both criteria are exceeded, the sediment is considered to be severely impacted. As it can be seen from the result of the analyses (Table 1) the content levels of Manganese, Cobalt, Chromium, Cupper, Iron, Lead and Zinc are low and beneath the contamination levels in the samples from all the study area.

Cadmium concentrations in the samples taken from all the study area are relatively high (0.002$6.7 \mathrm{ppm})$ and above the lowest levels (0.6-9.0 ppm; Table 2). Cadmium is potentially toxic element and has a long biological life of 20-30 years in the kidney [15]. Continual exposure may in the long run accumulate cadmium to significant levels in biological tissues [16]. Exposure of aquatic organisms to cadmium can result in various adverse effects, including acute mortality, reduced growth, and inhibited reproduction [17]. In general, cadmium is considered to have an extensive residence time and can accumulate to significant levels in biological tissues [16]. The main anthropogenic sources of cadmium appear industries involved in the manufacture of alloys, paints, batteries, and plastics, agricultural uses of sludge, fertilizers and pesticides that contain cadmium, and the burning of fossil fuels [18]. 
(a)

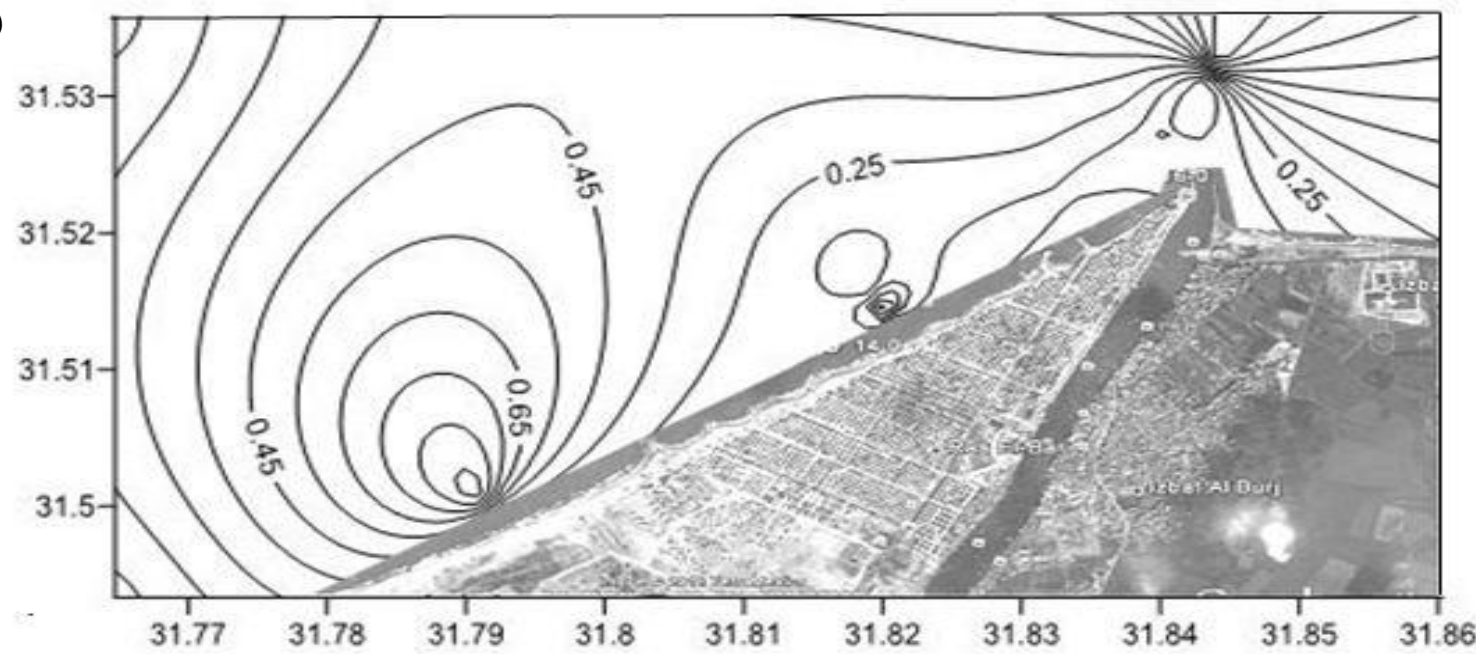

(b)
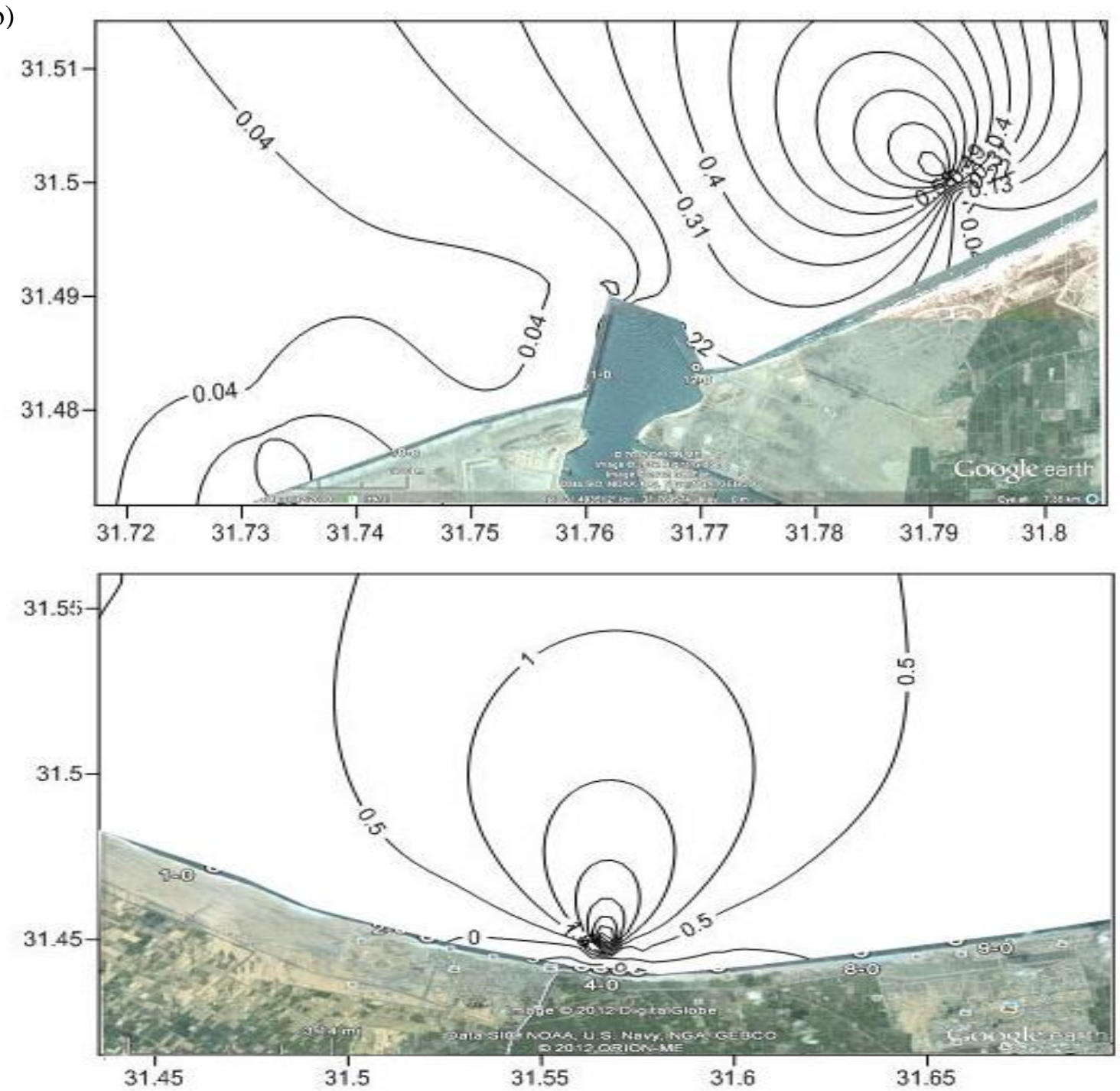

Fig. 2 Cadmium distribution along Ras El Bar sector (a), Damietta Port sector (b), and New Damietta CityGamasa sector (c) 
Table 2 Risk levels for metals contamination in sediments. Modified from the Technical Guidance for Screening Contaminated Sediments, New York State Department of Environmental Conservation. Division of Fish, Wildlife and Marine Resources, 1999, after Persaud et al. [14], Long and Morgan [13]

\begin{tabular}{lll}
\hline Metal & $\begin{array}{l}\text { Lowest Effect } \\
\text { Level } \\
\mu \mathrm{g} \mathrm{g}^{-1}(\mathrm{ppm})\end{array}$ & $\begin{array}{l}\text { Severe Effect } \\
\text { Level } \\
\mu \mathrm{g} \mathrm{g}^{-1}(\mathrm{ppm})\end{array}$ \\
\hline Cadmium & $0.6(\mathrm{P})$ & $9.0(\mathrm{~L})$ \\
Chromium & $26.0(\mathrm{P})$ & $110.0(\mathrm{P})$ \\
Copper & $16.0(\mathrm{P})$ & $110.0(\mathrm{P})$ \\
Iron $(\%)$ & $2.0 \%(\mathrm{P})$ & $4.0 \%(\mathrm{P})$ \\
Lead & $31.0(\mathrm{P})$ & $110.0(\mathrm{~L})$ \\
Manganese & $460.0(\mathrm{P})$ & $1100.0(\mathrm{~L})$ \\
Mercury & $0.15(\mathrm{~L})$ & $1.3(\mathrm{~L})$ \\
Zinc & $120.0\left(\mathrm{P} \mathrm{L}^{-1}\right)$ & $270.0(\mathrm{~L})$
\end{tabular}

An "L" following a criterion means that it was taken from Long and Morgan [13]; a "P" following a criterion indicates that it is from Persaud et al. [14].

Investigating the distribution of the cadmium in the sediment samples indicates $0.065-6.7 \mathrm{ppm}$ near the outlet of Gamasa drain. The dominant dispersal path is directed eastwards by the prevailing alongshore littoral current. At about 12 $\mathrm{km}$ distance from the outfall the cadmium levels in sediments were diminished at about 0.002$1.128 \mathrm{ppm}$.

In the study area, Samples taken from seafloor in front of Gamasa drain outlet show the relative highest level of contamination with cadmium (6.7ppm). This peak of cadmium content strongly indicates that the main cause for sediment contamination with cadmium is dumping of industrial and agriculture wastes through Gamasa main drains.

Mercury has been detected in the beach and near shore samples from all the coast of study area (Except of the beach of New Damietta City) with levels of concentration exceed the permissible levels and present environmental hazards (Table 2) (Fig. 3). The maximum concentration observed in the front of the main drain of Gamasa $\left(2.9 \mu \mathrm{g} \mathrm{g}^{-1}\right)$. In front of Damietta Port it reaches to $1.15 \mu \mathrm{g} \mathrm{g}^{-1}$ and in the beach of Ras El Bar it reaches to $0.8 \mu \mathrm{g} \mathrm{g}^{-1}$. In the beach of New Damietta City Mercury is not detected.

Mercury is extremely toxic to marine organisms, wildlife, and man. Mercury can be rapidly spread from its natural and anthropogenic sources because of its volatility. Most of the mercury complexes with dissolved or particulate organic matter and may settle with it and accumulated in sediments. These properties combined with its vast bio magnification in the food chain, make it the metal of the most environmental concern (e.g., $[19,20]$ ). The anthropogenic mercury sources are both diffuse and local. The diffuse sources are mainly the burning of fossil fuel, especially coal, the incineration of municipal solid waste, and the cement production; the local sources consist mainly of effluents from industrial activities $[21,22]$. The concentration peaks of mercury in sediments of the study area occur near oil industries (liquefied natural gas (LNG) complex in new Damietta City) and the main drains (Gamasa, and Kitchener).

Trace metals may be accumulated in sediments by three possible mechanisms: 1) physico-chemical adsorption from the water column, 2) biological uptake by organic matter or organisms, and 3) physical accumulation of metal enriched particulate matter by sedimentation. Texture of sediments is particularly important in determining the fate and accumulation of environmental contaminants. According to Tam and Wong [23] $\mathrm{Cu}, \mathrm{Zn}, \mathrm{Mn}, \mathrm{Pb}, \mathrm{Ni}, \mathrm{Ba}, \mathrm{Cd}$ and $\mathrm{Fe}$ tend to be accumulated in finer sized sediments. On the other hand, Elewa [8] reported that Bottom sediments with sand-sized fraction would accumulate metals if they received heavy metals from prolific anthropogenic source. In the present study, the performed grain size analysis on the collected beach and bottom sediments samples of study area revealed no significant variation. All the studied samples are sand-sized fraction (fine sand), sample 1is the only sample containing very fine sand. Three samples only (4-1, 12-1 and 14-1 are medium sand.

In the study area there are many probable sources of pollution; Ras El Bar sewage drain, Damietta Port, the industrial zone near New Damietta City where The Spanish Egyptian Gas Company (SEGAS) liquefied natural gas (LNG) complex and Fertilizer Production Company (MOPCO) are situated on the Mediterranean Coast, Gamasa drain and the end of Damietta Nile branch where the famous shipyard of Ezbet El Bourg is located. Industrial activity is very intense in Gamasa cities and industrial effluents are discharged to Gamasa drain, then into the Mediterranean coast of Nile Delta. 

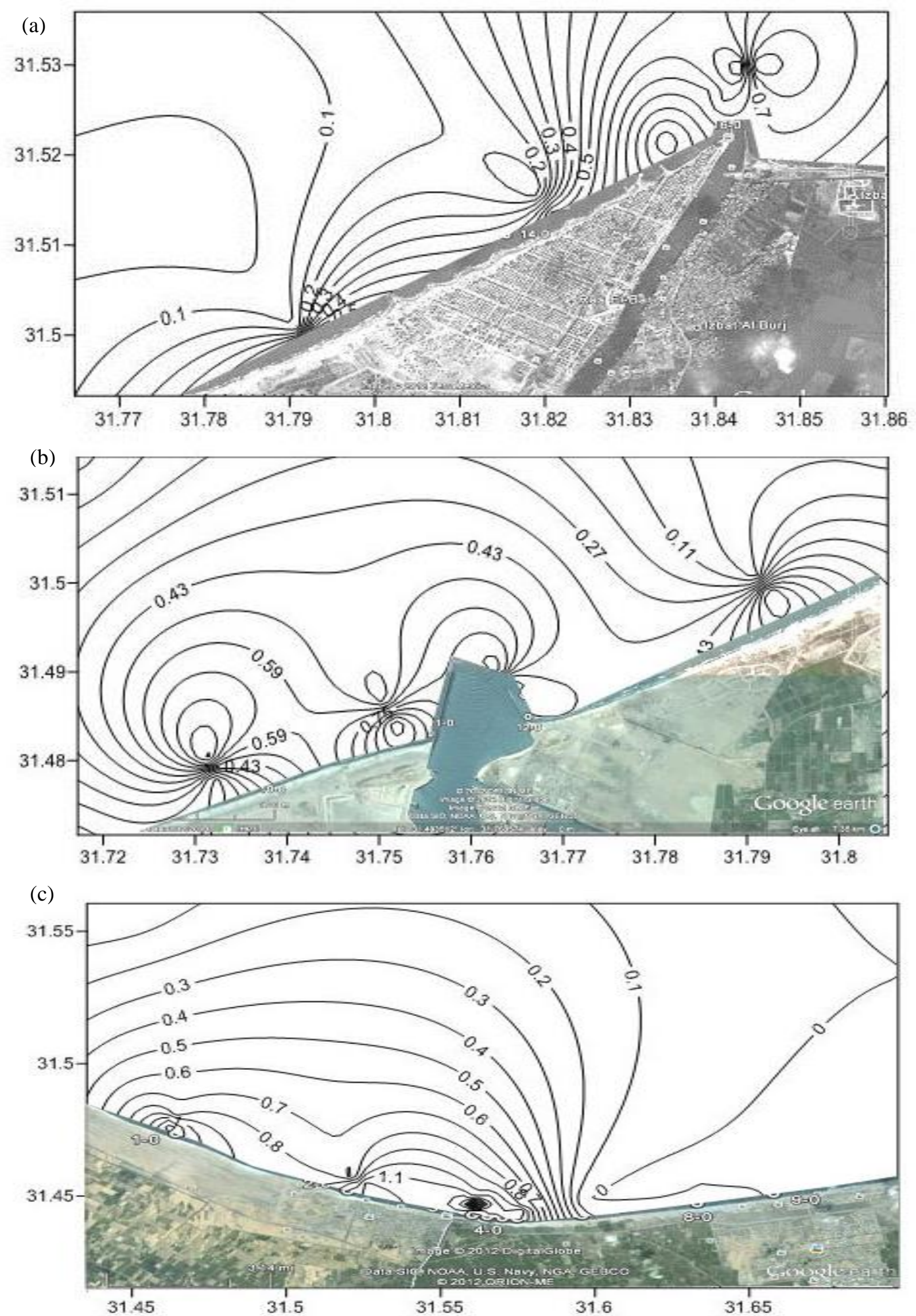

Fig. 3 Mercury distribution along Ras El Bar sector (a), Damietta Port sector (b), and New Damietta CityGamasa sector (c) 
Industrial and agriculture wastes include fertilizers, pesticides, organic chemicals, dyes, food processing and a wide variety of other organic contaminants. Sewage is introduced into these drains then to the coast of Nile Delta from the household activities of the nearby towns. In addition, Manzala Lagoon is located on the North-Eastern edge of the Nile Delta and discharges to the Mediterranean Sea through three outlets.

\section{Conclusions}

- Most heavy metals concentration in the beach and near shore sediments of the study area can be considered within the permissible levels and present little or no environmental hazards. However, some heavy metals such as Mercury $(\mathrm{Hg})$ and Cadmium (Cd) exhibit alerting hazardous levels, which need an attention and further monitoring.

- Sources for sediments pollution in the area are abundant and include sewage drains, Damietta Port, the industrial zone near New Damietta City where liquefied natural gas (LNG) complex and Fertilizer Production Company are situated, Gamasa and Kitchener main drains and the end of Damietta Nile branch where the famous shipyard of Ezbet el bourg is located.

- The potential point source for contamination of the sediment with cadmium is the main drain of Gamasa. Domestic, agricultural and the untreated industrial wastes are being directly dumped into the Mediterranean coast through the drain.

\section{References}

[1] W. Salomons, U. Forstner, Metals in the hydrocycle, Springer Publishing Co. Berlin, Heidelberg (1984) 349

[2] M. Soylak, U. Divrikli, S. Saracoglu, L. Elci, Monitoring trace metal levels in Yozgat-Turkey: Copper, Iron, Nickel, Cobalt, Lead, Cadmium, Manganese and Chromium Levels in Stream Sediments. Polish Journal of Environmental Studies 11 (2002) 47-51

[3] M. El-Sayed, M.A. El-Sayed, A. Mouss, Anthropogenic material in sediments from the Eastern harbor of Alexandria, Egypt, 9-13th CIESM Congress Proceedings (1980) 215-222

[4] F. El-Nady, Survey of some heavy metals in Alexandria water and its effect on some marine animals. Ph.D. Thesis, Alexandria University, (1981) 350

[5] O. Aboul Dahab, Y. Halim, Spatial distribution of tin compounds in sediments of Alexandria coastal belt, 31th CIESM Congress Proceedings (1988) 2

[6] S.M. Nasr, I.W. El-Sokkary, A.A. Fakhry, I.A. El-Shibiny, Pollution effects on coastal sediments of Alexandria, Proceedings of the Symposium on Environmental Sciences, UNARC (1988) 181-187

[7] M.A.H. Saad, N.B. Badr, Copper speciation in the sediments of the polluted eastern harbor of Alexandria, Egypt" in M.J. Bunch, V. Madha Suresh, T. Vasantha Kumaran, eds., Proceedings of the Third International Conference on Environment and Health, Chennai, India, 15-17 December (2003) Chennai: Department of Geography, University of Madras and Faculty of Environmental Studies, York University 417426

[8] H.H. Elewa, Potentialities of Water Resources Pollution of the Nile River Delta, Egypt, The Open Hydrology Journal, 4 (2010) 1-13

[9] A.M. Fanos, Statistical analysis of longshore current data along the Nile Delta coast. Water Science Journal 1 (1986) 45-55

[10] M. M. El- Banna, N. N. A. Hasaneen, Transport rate and distribution of longshore sediments along the Coast of Ras El-Bar, Nile Delta, Egypt. J. Environmental Sciences, El Mansoura Uinv. Egypt 23 (2002) 71-86

[11] D.L. Inman, S.A. Jenkins, The Nile littoral cell and man's impact on the coastal zone of the southeastern Mediterranean. Scripps Inst. Oceanogr. Ref .Ser. 31 (1984) 1-43

[12] W.L. Lindsay, W. Norvell, A new test for the simultaneous determination of available zinc and iron. Meeting of the western soil science society. Los Angeles, Calif. June (1967)

[13] E.R. Long, L.G. Morgan, The potential for biological effects of sediment-sorbed contaminants tested in the national states and trends program. National Oceanic Atmospheric Administration (NOAA) Technical Memorandum No. 5, OMA52, NOAA National Ocean Service, Seattle, Washington (1990)

[14] D. Persaud, R. Jaagumagi, A. Hayton, Guidelines for the Protection and Management of Aquatic Sediment Quality in Ontario. Ontario Ministry of the Environment, Queen's Printer for Ontario. (1992)

[15] WHO (World Health Organization), IPCS environmental health criteria 134 Cadmium. WHO, Geneva (1992)

[16] R. Jaagumagi, Development of the Ontario provincial sediment quality guidelines for arsenic, cadmium, chromium, copper, iron, lead, manganese, mercury, nickel, and zinc. Water Resources Branch. Environment Ontario. Toronto, Ontario (1990) 10

[17] R. Eisler, Cadmium hazards hazards to fish, 
wildlife, and invertebrates: A synoptic review, Contaminant Hazard Reviews, Report No. 2 (1985)

[18] CCREM (Canadian Council of Resource and Environmental Ministers), Canadian water quality guidelines for the protection of aquatic life (1987)

[19] M.M.F. Morel, M.L.A. Kraepiel, M. Amyot, The chemical cycle and bioaccumulation of mercury. Annu. Rev. Ecol. Sys. 29 (1998) 543-566

[20] W.F. Fitzgerald, C.H. Lamborg, C.R. Hammerschmidt, Marine biogeochemical cycling of mercury. Chem. Rev. 107 (2007) 641-662

[21] J.E. Sanchez Uria, A. Sanz-Mendel, Inorganic and methylmercury speciation in environmental samples. Talanta 47 (1998) 509-524

[22] N. Pirrone, R. Ferrara, I.M. Hedgecock, G. Kallos, Y. Mamane, J. Munthe, J.M. Pacyna, I. Pytharoulis, F. Sprovieri, A. Voudouri, I. Wangberg, Dynamic processes of mercury over the Mediterranean region: results from the Mediterranean Atmospheric Mercury Cycle System (MAMCS) project. Atmos. Environ. 37 Supplement No. 1 (2003) S21-S39

[23] N.F.Y. Tam, Y.S. Wong, Spatial variation of heavy metals in surface sediments of Hong Kong mangrove swamps. Environ. Pollut. 110 (2000) 195-205 